\title{
Marinococcus halotolerans sp. nov., isolated from Qinghai, north-west China
}

Correspondence

Wen-Jun Li

wjli@ynu.edu.cn or

lihxu@ynu.edu.cn

\author{
Wen-Jun Li, ${ }^{1}$ Peter Schumann, ${ }^{2}$ Yu-Qin Zhang, ${ }^{1}$ Guo-Zhong Chen, ${ }^{1}$ \\ Xin-Peng Tian, ${ }^{1}$ Li-Hua Xu, ${ }^{1}$ Erko Stackebrandt ${ }^{2}$ and Cheng-Lin Jiang ${ }^{1}$
}

\begin{abstract}
${ }^{1}$ The Key Laboratory for Microbial Resources of Ministry of Education, Yunnan Institute of Microbiology and Laboratory for Conservation and Utilization of Bio-Resources, Yunnan University, Kunming, Yunnan, 650091, P. R. China

${ }^{2} \mathrm{DSMZ}$ - Deutsche Sammlung von Mikroorganismen und Zellkulturen GmbH, Mascheroder Weg 1b, D-38124 Braunschweig, Germany
\end{abstract}

The genus Marinococcus was proposed to accommodate two species, Marinococcus albus and Marinococcus halophilus; both species were formerly classified as Planococcus species (Novitsky \& Kushner, 1976; Hao et al., 1984). They have meso-diaminopimelic acid in the cell wall, a DNA G + C content ranging between 43.9 and $46.6 \mathrm{~mol} \%$, a menaquinone system with MK-7, grow at a concentration of $20 \%$ $\mathrm{NaCl}$, and are motile cocci. A third Marinococcus species, Marinococcus hispanicus, has been transferred to the genus Salinicoccus (Ventosa et al., 1992). Therefore, at the time of writing, there are only two Marinococcus species with validly published names. M. halophilus is the predominant coccus found in most hypersaline environments (Ventosa et al., 1983; Márquez et al., 1992).

During our investigations of the extremophilic microbial flora of China (Tang et al., 2003; Li et al., 2004a, b, 2005a, b), strain YIM $70157^{\mathrm{T}}$ was recovered and characterized by a combination of genotypic and phenotypic methods. It was evident that the isolate was sufficiently distinct from the two species of the genus Marinococcus to warrant the description of a novel species, for which the name Marinococcus halotolerans sp. nov. is proposed.

Published online ahead of print on 22 April 2005 as DOI 10.1099/ ijs.0.63596-0.

The GenBank/EMBL/DDBJ accession number for the 16S rRNA gene sequence of strain YIM $70157^{\top}$ is AY817493.
Strain YIM $70157^{\mathrm{T}}$ was isolated from a hypersaline soil sample, collected from Qinghai, north-west China, by using the dilution plating method. Detailed information about the saline soils and salt lakes in Qinghai Province was given by Zhang et al. (1987). Modified medium SG (Sehgal \& Gibbons, 1960) used for selective isolation contained the following $\left(\mathrm{g}^{-1}\right)$ : Casamino acids $(7 \cdot 5)$, yeast extract $(10 \cdot 0)$, trisodium citrate $(3 \cdot 0), \mathrm{NaCl}(2 \cdot 0), \mathrm{KCl}(2 \cdot 0), \mathrm{MgCl}_{2} \cdot 6 \mathrm{H}_{2} \mathrm{O}$ (250), $\quad \mathrm{MgSO}_{4} .7 \mathrm{H}_{2} \mathrm{O} \quad(1 \cdot 0), \quad \mathrm{FeSO}_{4} \cdot 7 \mathrm{H}_{2} \mathrm{O} \quad(0 \cdot 05)$ and $\mathrm{MnSO}_{4} \cdot 7 \mathrm{H}_{2} \mathrm{O}(0 \cdot 0002) . \mathrm{MgCl}_{2} \cdot 6 \mathrm{H}_{2} \mathrm{O}$ was sterilized separately and then added to the medium. The plate was incubated at $28^{\circ} \mathrm{C}$ for 2 weeks. The isolate was maintained on modified SG agar slants that contained $10 \%(\mathrm{w} / \mathrm{v})$ $\mathrm{MgCl}_{2} \cdot 6 \mathrm{H}_{2} \mathrm{O}$ at $4{ }^{\circ} \mathrm{C}$ and as glycerol suspensions $(20 \%$, w/v) at $-20^{\circ} \mathrm{C}$. Biomass for chemical and molecular systematic studies was obtained from enrichment agar plates of modified SG agar medium incubated at $28{ }^{\circ} \mathrm{C}$ for about $4-5$ days.

The morphology and motility of cells grown for $10-48 \mathrm{~h}$ on modified SG agar were examined by using light microscopy (model BH 2; Olympus) and transmission electron microscopy (model H-800; Hitachi). For transmission electron microscopy observation, cells were negatively stained with $1 \%(\mathrm{w} / \mathrm{v})$ phosphotungstic acid, after air drying. Observation of flagella was also performed using the Leifson flagella staining method (Leifson, 1960). Gram staining was carried out using the standard Gram reaction combined with the 
KOH lysis test method (Cerny, 1978). The colony colour of the isolate grown on modified SG agar medium was determined by comparing the cultures with the most suitable colour chips from the ISCC-NBS colour charts (Kelly, 1964). Growth at different temperatures, salt $(\mathrm{NaCl}, \mathrm{KCl}$ and $\mathrm{MgCl}_{2} \cdot 6 \mathrm{H}_{2} \mathrm{O}$ ) concentrations and $\mathrm{pH}$ values was investigated as described by Tang et al. (2003), except that modified SG was used as the basic medium. Metabolic properties were determined using the API ID 32E test kits (bioMérieux) according to the manufacturer's instructions. Other physiological and biochemical tests were performed as described previously (Li et al., 2004a, b, 2005a, b).

Peptidoglycan was purified and the cell-wall amino acids and peptides in cell-wall hydrolysates were analysed by twodimensional ascending TLC on cellulose plates using the solvent systems of Schleifer \& Kandler (1972). The diaminopimelic acid isomer was identified by using the method of Rhuland et al. (1955). Analyses of polar lipids and menaquinones were performed according to published procedures (Groth et al., 1999). Analysis of the whole-cell fatty acid pattern was performed according to previously described methods (Miller, 1982) using the MIDI system (Microbial ID).

Extraction and amplification of genomic DNA for 16S rRNA gene sequence analysis were carried out as described previously (Xu et al., 2003). The DNA G + C content of strain YIM $70157^{\mathrm{T}}$ was determined by reverse-phase HPLC of nucleosides according to Mesbah et al. (1989). DNA-DNA hybridization was carried out by applying the optical renaturation method (De Ley et al., 1970; Huß et al., 1983; Jahnke, 1992) under optimal hybridization conditions.

Multiple alignments with sequences of a broad selection of related species of the order Bacillales and calculations of levels of sequence similarity were carried out using CLUSTAL X (Thompson et al., 1997). A phylogenetic tree (Fig. 1) was reconstructed using the neighbour-joining method of Saitou \& Nei (1987) from $K_{\text {nuc }}$ values (Kimura, 1980, 1983). The topology of the phylogenetic tree was evaluated by the bootstrap resampling method of Felsenstein (1985), with 1000 replicates.

Cells of strain YIM $70157^{\mathrm{T}}$ were aerobic, Gram-positive, nonspore-forming, motile and spherical; each cell possessed a single polar flagellum and was about $1 \cdot 0-1 \cdot 2 \mu \mathrm{m}$ in diameter (not shown). Colonies of YIM $70157^{\mathrm{T}}$ were orange, circular, lubricious and opaque on most agar media tested. The strain grew optimally in modified SG medium at $28{ }^{\circ} \mathrm{C}$ at $\mathrm{pH} 7 \cdot 0-7 \cdot 5$ and in the presence of $10 \cdot 0 \%(\mathrm{w} / \mathrm{v})$ $\mathrm{MgCl}_{2} \cdot 6 \mathrm{H}_{2} \mathrm{O}\left(\mathrm{MgCl}_{2} \cdot 6 \mathrm{H}_{2} \mathrm{O}\right.$ can also be substituted by $\mathrm{NaCl}$ or $\mathrm{KCl}$ ); the concentration ranges of $\mathrm{MgCl}_{2} \cdot 6 \mathrm{H}_{2} \mathrm{O}, \mathrm{NaCl}$ and $\mathrm{KCl}$ for growth were $0-20,0-25$ and $0-25 \%$, respectively. Strain YIM $70157^{\mathrm{T}}$ could utilize maltose, mannitol, glucose, mannose, fructose, cellobiose, salicin, acetamide, galactose, xylose and dextrin as carbon sources, but could not use adonitol, arabinose, arabitol, rhamnose, inositol or sorbitol. Acid was produced only from aesculin, glucose and mannitol. Other physiological properties are given in detail in Table 1 and in the species description.

The peptidoglycan type of strain YIM $70157^{\mathrm{T}}$ was A1 $\gamma$ based on meso-diaminopimelic acid. The phospholipids were phosphatidylinositol and diphosphatidylglycerol. The menaquinones were MK-7 (91.6\%) and MK-6 (8.4\%). The major fatty acids were ai- $\mathrm{C}_{15: 0}(37 \cdot 40 \%)$, ai- $\mathrm{C}_{17: 0}(21 \cdot 11 \%)$ and $\mathrm{i}-\mathrm{C}_{16: 0}(9 \cdot 07 \%)$; the complete profile of cellular fatty acids is given in detail in the species description.

Comparison of the almost-complete 16S rRNA gene sequence (1453 nucleotide positions) of strain YIM $70157^{\mathrm{T}}$ with homologous sequences of a wide range of related type strains revealed that the closest phylogenetic relatedness is to M. halophilus DSM $20408^{\mathrm{T}}$ ( $99 \cdot 4 \%$ sequence similarity). The heterogeneity with respect to the second Marinococcus type strain, M. albus DSM $20748^{\mathrm{T}}$, was significantly higher (only $89.5 \%$ sequence similarity). A distance-matrix dendrogram is presented in Fig. 1. The 20.8\% DNA-DNA relatedness determined between strain YIM $70157^{\mathrm{T}}$ and $M$. halophilus DSM $20408^{\mathrm{T}}$ was significantly lower than the $70 \%$ value considered to be the recommended threshold value for the delineation of genomic species (Wayne et al., 1987).

The result of the 16S rRNA gene sequence comparisons clearly demonstrated that strain YIM $70157^{\mathrm{T}}$ is a member of the genus Marinococcus. Similarities in some phenotypic characteristics with respect to the only two type strains further support the inclusion of strain YIM $70157^{\mathrm{T}}$ in the

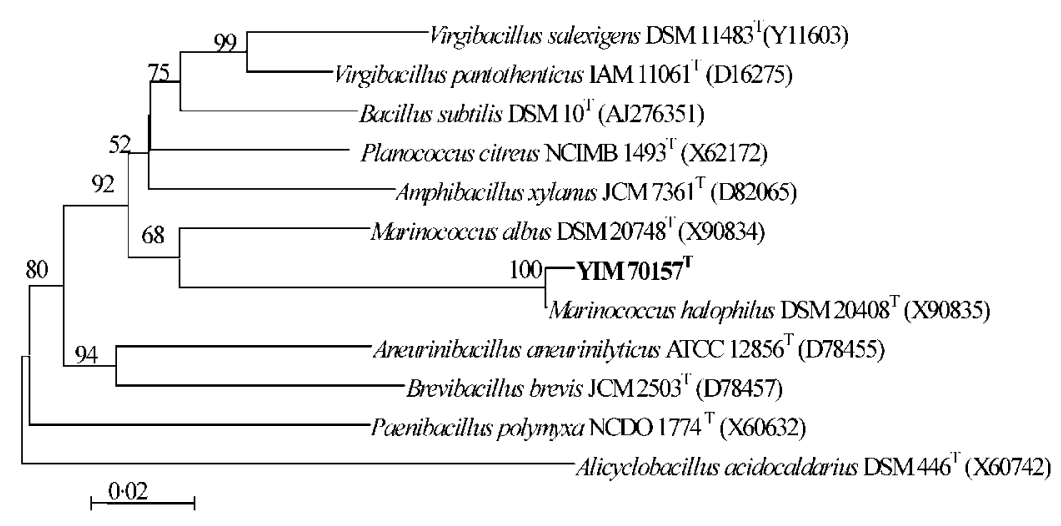

Fig. 1. Phylogenetic dendrogram obtained by distance matrix analysis of $16 \mathrm{~S}$ rRNA gene sequences, showing the position of strain YIM $70157^{\top}$ among phylogenetic neighbours. Numbers on branch nodes are bootstrap values (1000 resamplings). The sequence of Alicyclobacillus acidocaldarius DSM $446^{\top}$ was used as a root. Bar, $1 \%$ sequence divergence. 
Table 1. Differential phenotypic characteristics among strains YIM $70157^{\top}$, M. halophilus DSM $20408^{\top}$ and $M$. albus DSM $20748^{\top}$

All three strains are aerobic, Gram-positive, non-spore-forming, motile cocci with flagella. All have the meso-diaminopimelic acid cell wall type and have MK-7 as the major menaquinone system. All are catalase-positive, give negative results in the methyl red and VogesProskauer tests, and are negative for melanin production, $\mathrm{H}_{2} \mathrm{~S}$ and indole production; Tweens 20 and 80 and starch are not decomposed. All are $\beta$-glucosidase-, $\beta$-galactosidase- and lipase-positive, but negative for arginine dihydrolase, ornithine decarboxylase, L-aspartic arylamidase and growth in cellulose. All utilize maltose, mannitol, glucose, mannose, fructose, salicin, acetamide and galactose as sole carbon sources, but do not utilize adonitol, arabinose, arabitol, inositol, rhamnose or sorbitol. Data for M. halophilus DSM 20408 ${ }^{\mathrm{T}}$ and $M$. albus DSM $20748^{\mathrm{T}}$ are from Hao et al. (1984). Symbols: +, positive; -, negative.

\begin{tabular}{|c|c|c|c|}
\hline Characteristic & M. halotolerans YIM $70157^{\mathrm{T}}$ & M. halophilus DSM $20408^{\mathrm{T}}$ & M. albus DSM $20748^{\mathrm{T}}$ \\
\hline Colony pigmentation (PYGV medium ${ }^{\star}$ ) & Orange & Yellow-orange & White \\
\hline $\mathrm{pH}$ tolerance & $6 \cdot 5-9 \cdot 0$ & $6 \cdot 0-10 \cdot 0$ & $6 \cdot 0-10 \cdot 0$ \\
\hline Growth without salt & + & - & - \\
\hline Acid production from fructose & - & + & - \\
\hline Cellobiose & + & - & - \\
\hline Dextrin & + & - & - \\
\hline Mannose & + & - & - \\
\hline \multicolumn{4}{|l|}{ Hydrolysis of: } \\
\hline Casein & - & + & - \\
\hline$\alpha$-Galactosidase & - & + & + \\
\hline Oxidase & - & - & + \\
\hline Major fatty acids (\%) & $\begin{aligned} \text { ai- } C_{15: 0} & (37 \cdot 4), \text { ai- } C_{17: 0}(21 \cdot 1), \\
\text { i- } C_{16: 0} & (9 \cdot 1), i-C_{17: 0}(7 \cdot 7), \\
i-C_{15: 0} & (6 \cdot 9), C_{16: 0}(6 \cdot 7)\end{aligned}$ & $\begin{array}{c}\text { ai- } C_{15: 0}(45), \text { ai- } C_{17: 0}(30), \\
\text { i- }_{16: 0}(14), C_{16: 0}(7)\end{array}$ & ai- $C_{15: 0}(64)$, ai- $C_{17: 0}$ (39) \\
\hline DNA G $+C$ content $(\mathrm{mol} \%)$ & $48 \cdot 5$ & $46 \cdot 4$ & $44 \cdot 9$ \\
\hline
\end{tabular}

${ }^{\star}$ Medium described by Staley (1968).

genus Marinococcus. However, strain YIM $70157^{\mathrm{T}}$ differs from M. halophilus DSM $20408^{\mathrm{T}}$ by the ability to utilize mannose, dextrin and cellobiose as sole carbon sources, oxidative acid production from aesculin, and some differences in enzymic properties (Table 1). DNA-DNA hybridization confirmed the differentiation of both strains at the species level. These pieces of evidence show that the novel isolate YIM $70157^{\mathrm{T}}$ represents a hitherto unknown species of Marinococcus, for which the name Marinococcus halotolerans sp. nov. is proposed.

\section{Description of Marinococcus halotolerans sp. nov.}

Marinococcus halotolerans (ha.lo.to'le.rans. Gr. n. hals salt; L. pres. part. tolerans tolerating; N.L. part. adj. halotolerans referring to the ability of the organism to tolerate high salt concentrations).

Aerobic, Gram-positive, non-spore-forming, motile, spherical with a single polar flagellum; cell diameter is about
$1 \cdot 0-1 \cdot 2 \mu \mathrm{m}$. The colony colour on most media tested is orange. Colonies are circular, opaque and approximately $1.5-1 \cdot 8 \mathrm{~mm}$ in diameter after $24 \mathrm{~h}$ at $28^{\circ} \mathrm{C}$. The optimum concentration of $\mathrm{MgCl}_{2} \cdot 6 \mathrm{H}_{2} \mathrm{O}$ for growth is $10 \%(\mathrm{w} / \mathrm{v}$ ) $\left(\mathrm{MgCl}_{2} \cdot 6 \mathrm{H}_{2} \mathrm{O}\right.$ can also be substituted by $\mathrm{NaCl}$ or $\left.\mathrm{KCl}\right)$. The optimum growth $\mathrm{pH}$ and temperature are $7 \cdot 0-7 \cdot 5$ and $28{ }^{\circ} \mathrm{C}$, respectively. Concentration ranges of $\mathrm{MgCl}_{2} \cdot 6 \mathrm{H}_{2} \mathrm{O}$, $\mathrm{NaCl}$ and $\mathrm{KCl}$ for growth are $0-20,0-25$ and $0-25 \%$, respectively. Catalase-positive and oxidase-negative. Positive for nitrate reduction, but negative for gelatin liquefaction, ammonia production, in methyl red and Voges-Proskauer tests, and for milk peptonization and coagulation, growth on cellulose, $\mathrm{H}_{2} \mathrm{~S}$ and melanin production, casein and starch hydrolysis. The following substrates are utilized: maltose, mannitol, glucose, mannose, fructose, cellobiose, salicin, acetamide, galactose, xylose and dextrin. Adonitol, arabinose, arabitol, rhamnose, inositol and sorbitol are not utilized. Acid is produced from aesculin, glucose and mannitol. The peptidoglycan type is A $\gamma \gamma$ (meso-diaminopimelic acid directly cross-linked). The phospholipids 
contain phosphatidylinositol and diphosphatidylglycerol. The menaquinones are MK-7 (91.6\%) and MK-6 (8.4\%). The fatty acid profiles contain ai- $\mathrm{C}_{15: 0}(37 \cdot 4 \%)$, ai- $\mathrm{C}_{17: 0}$ $(21 \cdot 11 \%)$, i-C $16: 0 \quad(9 \cdot 07 \%), \quad$ i- $C_{17: 0}(7 \cdot 69 \%), \quad$ i- $C_{15: 0}$ $(6.92 \%), \mathrm{C}_{16: 0}(6.68 \%)$ and small amounts of $\mathrm{C}_{14: 0}$ $(0 \cdot 54 \%), C_{15: 0}(0 \cdot 55 \%), C_{17: 0}(0 \cdot 42 \%), C_{18: 0}(0 \cdot 67 \%)$, i- $\mathrm{C}_{14: 0}(2 \cdot 4 \%), \mathrm{i}-\mathrm{C}_{18: 0}(0 \cdot 76 \%), \mathrm{i}-\mathrm{C}_{19: 0}(0 \cdot 12 \%)$, ai-C $\mathrm{C}_{19: 0}$ $(0 \cdot 25 \%), \mathrm{C}_{16: 1} \omega 7 c(0 \cdot 36 \%), \mathrm{C}_{16: 1} \omega 11 c(1 \cdot 16 \%), \mathrm{C}_{18: 1} \omega 9 c$ $(0 \cdot 16 \%)$, i- $\mathrm{C}_{17: 1} \omega 10 c(0 \cdot 11 \%)$ and $\mathrm{C}_{16: 1} \omega 7 c$ alcohol $(3 \cdot 14 \%)$. The DNA G $+\mathrm{C}$ content is $48 \cdot 5 \mathrm{~mol} \%$ (HPLC method).

Isolated from a saline soil sample collected from Qinghai, north-west China. The type strain is YIM $70157^{\mathrm{T}}(=\mathrm{DSM}$ $16375^{\mathrm{T}}=$ KCTC $19045^{\mathrm{T}}$ ).

\section{Acknowledgements}

This research was supported by the National Basic Research Program of China (2004CB719601), the National Natural Science Foundation of China (30270004) and the Yunnan Provincial Natural Science Foundation (2004C0002Q).

\section{References}

Cerny, G. (1978). Studies on aminopeptidase for the distinction of Gram-negative from Gram-positive bacteria. Eur J Appl Microbiol Biotechnol 5, 113-122.

De Ley, J., Cattoir, H. \& Reynaerts, A. (1970). The quantitative measurement of DNA hybridization from renaturation rates. Eur J Biochem 12, 133-142.

Felsenstein, J. (1985). Confidence limits of phylogenies: an approach using the bootstrap. Evolution 39, 783-789.

Groth, I., Schumann, P., Martin, K., Schuetze, B., Augsten, K., Kramer, I. \& Stackebrandt, E. (1999). Ornithinicoccus hortensis gen. nov., sp. nov., a soil actinomycete which contains L-ornithine. Int J Syst Bacteriol 49, 1717-1724.

Hao, M. V., Kocur, M. \& Komagata, K. (1984). Marinococcus gen. nov., a new genus for motile cocci with meso-diaminopimelic acid in the cell wall; and Marinococcus albus sp. nov. and Marinococcus halophilus (Novitsky and Kushner) comb. nov. J Gen Appl Microbiol 30, 449-459.

Huß, V. A. R., Festl, H. \& Schleifer, K.-H. (1983). Studies on the spectrophotometric determination of DNA hybridization from renaturation rates. Syst Appl Microbiol 4, 184-192.

Jahnke, K. D. (1992). Basic computer program for evaluation of spectroscopic DNA renaturation data from GILFORD system 2600 spectrophotophotometer on a $\mathrm{PC} / \mathrm{XT} / \mathrm{AT}$ type personal computer. J Microbiol Methods 15, 61-73.

Kelly, K. L. (1964). Inter-society Color Council-National Bureau of Standards Color-name Charts Illustrated with Centroid Colors. Washington, DC: US Government Printing Office.

Kimura, M. (1980). A simple method for estimating evolutionary rates of base substitutions through comparative studies of nucleotide sequence. J Mol Evol 16, 111-120.

Kimura, M. (1983). The Neutral Theory of Molecular Evolution. Cambridge: Cambridge University Press.

Leifson, E. (1960). Atlas of Bacterial Flagellation. London: Academic Press.

Li, W.-J., Chen, H.-H., Zhang, Y.-Q., Schumann, P., Stackebrandt, E., Xu, L.-H. \& Jiang, C.-L. (2004a). Nesterenkonia halotolerans sp. nov. and Nesterenkonia xinjiangensis sp. nov., actinobacteria from saline soils in the west of China. Int J Syst Evol Microbiol 54, 837-841.

Li, W.-J., Chen, H.-H., Xu, P., Zhang, Y.-Q., Schumann, P., Tang, S.-K., Xu, L.-H. \& Jiang, C.-L. (2004b). Yania halotolerans gen. nov., sp. nov., a novel member of the suborder Micrococcineae from saline soil in China. Int J Syst Evol Microbiol 54, 525-531.

Li, W.-J., Chen, H.-H., Kim, C.-J., Park, D.-J., Tang, S.-K., Lee, J.-C., Xu, L.-H. \& Jiang, C.-L. (2005a). Microbacterium halotolerans sp. nov., isolated from a saline soil in the west of China. Int J Syst Evol Microbiol 55, 67-70.

Li, W.-J., Chen, H.-H., Zhang, Y.-Q., Kim, C.-J., Park, D.-J., Lee, J.-C., Xu, L.-H. \& Jiang, C.-L. (2005b). Citricoccus alkalitolerans sp. nov., a novel actinobacterium isolated from a desert soil in Egypt. Int J Syst Evol Microbiol 55, 87-90.

Márquez, M. C., Ventosa, A. \& Ruiz-Berraquero, F. (1992). Phenotypic and chemotaxonomic characterization of Maricoccus halophilus. Syst Appl Microbiol 15, 63-69.

Mesbah, M., Premachandran, U. \& Whitman, W. B. (1989). Precise measurement of the $\mathrm{G}+\mathrm{C}$ content of deoxyribonucleic acid by highperformance liquid chromatography. Int J Syst Bacteriol 39, 159-167.

Miller, L. T. (1982). Single derivatization method for routine analysis of bacterial whole-cell, fatty acid methyl esters, including hydroxy acids. J Clin Microbiol 16, 584-586.

Novitsky, T. J. \& Kushner, D. J. (1976). Planococcus halophilus sp. nov., a facultatively halophilic coccus. Int J Syst Bacteriol 26, 53-57.

Rhuland, L. E., Work, E., Denman, R. F. \& Hoare, D. S. (1955). The behaviour of the isomers of diaminopimelic acid on paper chromatograms. J Am Chem Soc 77, 4844-4846.

Saitou, N. \& Nei, M. (1987). The neighbor-joining method: a new method for reconstructing phylogenetic trees. Mol Biol Evol 4, 406-425. Schleifer, K. H. \& Kandler, O. (1972). Peptidoglycan types of bacterial cell walls and their taxonomic implications. Bacteriol Rev 36, 407-477.

Sehgal, S. N. \& Gibbons, N. E. (1960). Effect of metal ions on the growth of Halobacterium cutirubrum. Can J Microbiol 6, 165-169.

Staley, J. T. (1968). Prosthecomicrobium and Ancalomicrobium, new prosthecate freshwater bacteria. J Bacteriol 95, 1921-1944.

Tang, S.-K., Li, W.-J., Wang, D., Zhang, Y.-G., Xu, L.-H. \& Jiang, C.-L. (2003). Studies of the biological characteristics of some halophilic and halotolerant actinomycetes isolated from saline and alkaline soils. Actinomycetologica 17, 6-10.

Thompson, J. D., Gibson, T. J., Plewniak, F., Jeanmougin, F. \& Higgins, D.-G. (1997). The CLUSTAL $X$ windows interface: flexible strategies for multiple sequence alignment aided by quality analysis tools. Nucleic Acids Res 24, 4876-4882.

Ventosa, A., Ramos-Cormenzana, A. \& Kocur, M. (1983). Moderately halophilic gram-positive cocci from hypersaline environments. Syst Appl Microbiol 4, 564-570.

Ventosa, A., Marquez, M. C., Weiss, N. \& Tindall, B. J. (1992). Transfer of Marinococcus hispanicus to the genus Salinicoccus as Salinicoccus hispanicus comb. nov. Syst Appl Microbiol 15, 530-534.

Wayne, L. G., Brenner, D. J., Colwell, R. R. \& 9 other authors (1987). International Committee on Systematic Bacteriology. Report of the ad hoc committee on reconciliation of approaches to bacterial systematics. Int J Syst Bacteriol 37, 463-464.

Xu, P., Li, W.-J., Xu, L.-H. \& Jiang, C.-L. (2003). A microwave-based method for genomic DNA extraction from Actinomycetes. Microbiology (Beijing) 30, 73-75.

Zhang, P.-X., Chen, K.-Z., Yu, S.-S., Gao, Z.-H., Zhang, B.-Z., Li, J.-Y. \& Sun, D.-P. (1987). Salt Lakes in Chai Da Mu Basin. Beijing: Science Press. 